\title{
DROGA TIMORU WSCHODNIEGO DO ASEAN - CZŁONEK TRZECIEJ GENERACJI CZY WIECZNY OBSERWATOR?
}

\author{
Paweł Soja \\ Uniwersytet Jagielloński w Krakowie \\ Instytut Nauk Politycznych i Stosunków Międzynarodowych \\ e-mail: pawelsoja92@gmail.com
}

\begin{abstract}
Streszczenie: W roku 2017 państwa tworzące Stowarzyszenie Narodów Azji Południowo-Wschodniej obchodziły jubileusz 50-lecia powołania do życia wspólnoty. Jednym z bieżących i jednocześnie przyszłych wyzwań stojących przed tą organizacją jest poszerzenie struktur o kolejnych członków, w tym o starający się oficjalnie o przystąpienie do forum współpracy od $2011 \mathrm{r}$. Timor Wschodni. Celem poniższego artykułu jest przedstawienie relacji panujących pomiędzy wspólnotą ASEAN (Association of Southeast Asian Nations) a państwem Timor Wschodni z uwzględnieniem jego dotychczasowej ścieżki akcesyjnej oraz ocena mocnych i słabych stron zgłoszonej kandydatury wraz z odpowiedzią na pytanie o implikacje ewentualnego przyjęcia do struktur stowarzyszenia.
\end{abstract}

Słowa kluczowe: ASEAN, Azja Południowo-Wschodnia, organizacje międzynarodowe, Timor Wschodni, stosunki międzynarodowe, współpraca regionalna

\section{WSTĘP}

Timor Wschodni doświadczył w XX wieku jednej z największych zbrodni ludobójstwa, jakie miały miejsce w dotychczasowej historii. Okupacja wschodniej wyspy przez wojska indonezyjskie w latach 1975-1999 przyczyniła się do śmierci niemal 20\% ludności kraju, stanowiąc kolejny po analogicznych praktykach komunistów khmerskich ponury epizod w dziejach regionu w tamtym okresie [Harris, Goldsmith 2011]. Wieloletnia walka sił partyzanckich w połączeniu ze sprzyjającymi okolicznościami zewnętrznymi w postaci m.in. azjatyckiego kryzysu finansowego 1997 r. oraz w efekcie ustąpienie z urzędu prezydenta Indonezji generała Suharto umożliwiły w 1999 r. przeprowadzenie w Timorze referendum 
niepodległościowego, skutkiem czego trzy lata później kraj ponownie pojawił się na mapach świata. Od tego momentu Timor nie tylko konsoliduje swoją politykę wewnętrzną, podejmując wysiłki mające na celu odbudowę utraconej niegdyś państwowości, lecz także aktywnie i skutecznie działa na rzecz wzmocnienia relacji z otoczeniem międzynarodowym. W poszukiwaniu swojej regionalnej tożsamości urzędujący w Dili oficjele pozostają stroną licznych porozumień międzynarodowych i uczestniczą w forach multilateralnych na czele z Dialogiem Shangri-la, Procesem z Bali, Balijskim Forum Demokracji czy wspólnotą G7+.

Położenie na styku Azji Południowo-Wschodniej oraz obszaru wysp Pacyfiku, a także wciąż żywa wśród obywateli luzofońska przeszłość kolonialna pozwalają rządzącym na konstruowanie wielowektorowej polityki zagranicznej. Korzystne usytuowanie geograficzne jest dla Timoru szansą na stanie się nie tylko swoistym łącznikiem międzykulturowym, co w niedalekiej przyszłości może zagwarantować mu wzrost znaczenia w obrębie regionalnych stosunków międzysąsiedzkich, lecz także daje wolną rękę w wyborze kierunku, w jakim kraj chciałby rozwijać bardziej zintensyfikowane działania dyplomatyczne. Od samego początku tym podstawowym kierunkiem pozostaje rejon obejmujący kraje Stowarzyszenia Narodów Azji Południowo-Wschodniej (Association of Southeast Asian Nations - ASEAN), czego przykłady znajdują się jeszcze w archiwalnych wypowiedziach liderów państwa podziemnego sprzed 2002 r. oraz od wielu lat występują w dokumentach strategicznych kolejnych gabinetów rządowych [Secretariat of State of the Council of Minister, 2011]. Aspiracje Timoru do członkostwa w ASEAN potwierdza bliska współpraca z gremium, która doprowadziła do uzyskania statusu obserwatora oraz zorganizowania kilku wydarzeń w ramach jego agendy. Ukoronowaniem tych działań stało się złożenie w marcu 2011 r. do Sekretariatu ASEAN w Dżakarcie oficjalnego wniosku z aplikacją o członkostwo.

ASEAN powstało w 1967 r. w Bangkoku, a jego główną ambicją stało się utrzymanie pokoju, bezpieczeństwa i stabilności w rejonie Azji Południowo-Wschodniej oraz wzmacnianie wartości służących tym projekcjom. W latach 80. ubiegłego stulecia stowarzyszenie odegrało ważną rolę w negocjacjach pomiędzy aktorami zaangażowanymi w wojnę domową w Kambodży, jednak jego prawdziwy rozkwit nastąpił dopiero w kolejnej dekadzie. Przyczyniły się do tego zmiany polityczne po rozpadzie Związku Socjalistycznych Republik Radzieckich, wkroczenie gospodarki światowej w erę globalizacji oraz nieformalna rywalizacja pomiędzy ugrupowaniem oraz Chinami o rozszerzenie wpływów w regionie. Od 1992 r. jednym z priorytetów ASEAN jest zaawansowana współpraca gospodarcza, która doprowadziła m.in. do powstania Strefy Wolnego Handlu ASEAN. W międzyczasie rozrostowi uległ też regionalny podsystem organizacji. Pojawienie się takich form kooperacji, jak ASEAN+1, ASEAN+3 czy Szczyt Wschodnioazjatycki, przypieczętowało gospodarczy zwrot w polityce bloku, podczas gdy dodatkowy filar pod postacią Forum Regionalnego ASEAN (ASEAN Regional Forum - ARF) miał za zadanie wzmocnić makroregionalną architekturę bezpie- 
czeństwa przez zaproszenie do udziału w nim światowych mocarstw na czele ze Stanami Zjednoczonymi, Chinami, Rosją oraz Unią Europejską.

Dzisiaj ASEAN to wspólnota licząca $625 \mathrm{mln}$ mieszkańców, z których ponad połowa to ludzie poniżej trzydziestego roku życia. Młode społeczeństwo stanowi jego najcenniejszy kapitał, natomiast gospodarka ze stałym średnim wzrostem na poziomie ponad $5 \%$ rocznie i PKB równym 2,5 bln dolarów jest siódmą największą na świecie [Focus Economics 2015]. Co dziesiąta bezpośrednia inwestycja zagraniczna trafia do któregoś z krajów bloku, a jego bliskie relacje z innymi ponadregionalnymi inicjatywami pokroju Wspólnoty Gospodarczej Azji i Pacyfiku czy Wszechstronnego Regionalnego Partnerstwa każą upatrywać w nim jedno z kluczowych centrów procesów globalizacyjnych w najbliższych dekadach. Powołanie do życia w grudniu 2015 r. Wspólnoty Gospodarczej ASEAN (ASEAN Economic Community - AEC) stanowi przełom w dotychczasowej integracji, w dalszej perspektywie jest utworzenie zespolonego z globalnymi podmiotami wspólnego rynku opartego wzorem Unii Europejskiej na czterech swobodach przepływu kapitału, dóbr, inwestycji i siły roboczej.

Osiągnięcia na polu gospodarczym, mające rzeczywiste odzwierciedlenie m.in. w podwojeniu średniego PKB państw w latach 2000-2013 czy też redukcji o niemal 30\% liczby obywateli żyjących poniżej progu ubóstwa w najbiedniejszych krajach członkowskich, są czynnikami przemawiającymi do wyobraźni polityków tych narodów, które nie są jeszcze stowarzyszone z ASEAN [Pooittiwong, Ramirez 2016]. Pomimo korzeni sięgających lat 60. ubiegłego wieku porozumie jest związkiem nastawionym na integrację $\mathrm{w}$ ramach nowoczesnego modelu regionalizmu otwartego. Nie pozostaje organizacją zamkniętą, posiada stosunkowo luźne kryteria integracyjne. Wielu badaczy uważa więc, że jedynie kwestią czasu pozostaje poszerzenie jej składu o członków trzeciej generacji, a potencjalnie największe szanse przypisuje się w tym kontekście Papui Nowej Gwinei, Sri Lance oraz Timorowi Wschodniemu ${ }^{1}$. Kandydatura ostatniego z tych państw jest obecnie przedmiotem analizy pod kątem jej możliwych implikacji dla funkcjonowania ugrupowania, jednak natłok biurokratycznych procedur, ich niejasny status oraz powściągliwość i opieszałość organów ASEAN powodują, że przypadek Timoru urasta powoli do rangi nigdy niekończącej się sagi.

\section{DOTYCHCZASOWA DROGA TIMORU WSCHODNIEGO DO ASEAN}

Portugalska „rewolucja goździków” z kwietnia 1974 r. przyniosła ze sobą obietnicę, że wszystkie terytoria zamorskie Lizbony zostaną wkrótce oswobodzone, a ich ludność dostanie prawo zadecydowania o niepodległości i niezależności

1 Pierwsza generacja członków obejmuje kraje założycielskie (Filipiny, Indonezja, Malezja, Singapur, Tajlandia) oraz przyłączone w 1984 r. Brunei, podczas gdy do drugiego pokolenia uczestników zalicza się tzw. państwa CLMV: Kambodżę (1999), Laos (1997), Mjanmę (1997) i Wietnam (1995). 
od metropolii. Wiarę tę umocniła wydana 26 lipca 1974 r. poprawka do konstytucji, w której parlament uznał prawo kolonii do samostanowienia i unieważnił zapisy dotyczące ich pełnej integralności z terytorium Portugalii [Bernatowicz-Bierut 1982]. W odniesieniu do Timoru Wschodniego pomyślne wiadomości z drugiego końca świata skutkowały szybkim rozkwitem formacji zdolnych rywalizować o przywództwo polityczne, chociaż formy zorganizowanego sprzeciwu wobec panowania Portugalii dotychczas niemalże nie istniały [Bonczol 2008]. Jeszcze zanim w dniu 28 listopada 1975 r. Timor Wschodni ogłosił niepodległość, przedstawiciel dominującej partii Socjaldemokratycznego Związku Timoru (Associação Social-Democrata Timorense - ASDT) José Ramos-Horta spotkał się z ministrem spraw zagranicznych Indonezji Adamem Malikiem, otrzymując zapewnienie, że nowe państwo otrzyma wsparcie ze strony rządu indonezyjskiego, a przyjacielskie relacje pomiędzy narodami będą pielęgnowane niezależne od pozostających przy władzy opcjach politycznych. W rozmowie poruszono również wątek akcesji Timoru do ASEAN, a ze strony ministra Malika wystosowano propozycję dołączenia do wspólnoty [Hicks 2015].

W kolejnych miesiącach, już po przekształceniu ASDT w Rewolucyjny Front Niepodległego Timoru Wschodniego (Frente Revolucionária de Timor-Leste Independente - FRETILIN), dominująca partia kontynuowała dialog z ASEAN, bazując na kolektywnie podzielanych poglądach odnośnie do optymalnego modelu państwowości, niezaangażowania i suwerenności stron czy kooperacji w regionie na zasadach dobrego współsąsiedztwa. Szefostwo FRETILIN zaproponowało nawet utworzenie wspólnej misji z ASEAN, której celem byłoby patrolowanie rejonów przy granicy z Indonezją dla zapewniania większego bezpieczeństwa, a na dwa miesiące przed inwazją działacze Frontu wydali oświadczenie gloryfikujące dyplomację wspólnoty ze względu na jej działania na rzecz utrzymywania regionalnej równowagi i pokoju [Ortuoste 2011]. Ostatecznie niechęć części marksistowskich stronników Ramosa-Horty wobec akcesji do uznawanej w kuluarach za bastion imperializmu organizacji, w połączeniu z nagłą i niespodziewaną napaścią Dżakarty na wschodnią część wyspy uniemożliwiły dalsze kroki wobec bardziej zaawansowanych planów integracji.

Kiedy Indonezja dokonała inwazji na terytorium Timoru Wschodniego w grudniu 1975 r., państwa ASEAN nie podjęły żadnej znaczącej próby wpłynięcia na politykę generała Suharto i nie dążyły do uruchomienia mechanizmów mających na celu unormowanie sytuacji w regionie z punktu widzenia obowiązującego dotychczas status quo. Zagadnienie indonezyjskiej interwencji poddano analizie podczas Forum Ministrów Spraw Zagranicznych ASEAN latem 1976 r., lecz zgodnie z komunikatem końcowym ,delegaci z wdzięcznością wysłuchali przemowy ministra spraw zagranicznych Indonezji Adama Malika, który stwierdził, że rozwój wydarzeń w Timorze Wschodnim postępuje w zgodzie z zaleceniami rezolucji Rady Bezpieczeństwa ONZ" [Severino 2006]. Inkorporacja dawnej kolonii jako dwudziestej siódmej prowincji państwa indonezyjskiego w lipcu 1976 r. została zbyta całkowitym milczeniem. Jedynie działania dyplomatyczne 
Singapuru można uznać za pewien przejaw dezaprobaty. Tamtejszy ambasador przy Organizacji Narodów Zjednoczonych (ONZ) pośrednio odmówił legalności inwazji podczas uchwalenia rezolucji potępiającej akt agresji z 22 grudnia 1975 r., wstrzymując się od głosu. Ten w dużej mierze symboliczny gest wywołał reakcję w postaci groźby zerwania współpracy gospodarczej na linii DżakartaSingapur oraz zamknięcia indonezyjskiej przestrzeni powietrznej dla samolotów singapurskich linii lotniczych [Gunn 2006]. W kolejnych ASEAN jednogłośnie opowiadał się przeciwko usunięciu wojsk okupanta z terenów Timoru, a bezsilne ONZ z czasem zaprzestało wydawania kolejnych rezolucji potępiających aneksję, uznając za wiążący ostatni tego rodzaju apel z 1982 r. [Bonzol 2008].

Stowarzyszenie Narodów Azji Południowo-Wschodniej przez długie lata nie interesowało się głębiej problematyką zbrodni, jakie reżim Suharto popełniał tuż przy jego granicy. W dokumentach organizacji nie sposób odnaleźć jakichkolwiek wzmianek związanych z sytuacją na wyspie, co stanowi dowód na skuteczną presję polityczną Indonezji oraz spełnienie jej życzenia, żeby problem timoryjski traktować jako wewnętrzne zmartwienie państwa. Nie należy również zapominać, że w latach 80. XX w. sygnatariusze Deklaracji z Bangkoku z dużo większą uwagą oraz niepokojem przypatrywali się rosnącej sile ugrupowań komunistycznych, których powstrzymaniu nadali priorytet w ramach konserwacji przestrzeni bezpieczeństwa. Obywatele Timoru zdawali się nie zrażać taką postawą, prowadząc walkę z okupantem oraz nadal widząc swoją przyszłość w ASEAN. W 1992 r. przyszły prezydent państwa Xanana Gusmão (2002-2007), który już wcześniej zjednoczył wszystkie ugrupowania ruchu wyzwolenia pod wspólnym sztandarem Narodowej Rady Oporu, opracował pokojowy plan przekazania władzy z powrotem w ręce narodu timoryjskiego. W trzeciej części dokumentu odniósł się do etapu pełnej niezależności państwa, kiedy jednym z głównym priorytetów dla nowo wybranego rządu stanie się aplikacja o przynależność do ONZ oraz ASEAN [Strating 2016].

Nieprzejednane stanowisko stowarzyszenia nie uległo zmianie nawet w obliczu stopniowo rosnącego umiędzynarodowienia kwestii Timoru Wschodniego za sprawą takich wydarzeń, jak masakra na cmentarzu w Santa Cruz w 1991 r., powstanie stowarzyszeń pokroju East Timor Action Network czy East Timorese Relief Association, które zajęły się organizacją pomocy humanitarnej czy też przyznaniem Pokojowej Nagrody Nobla dla Ramosa-Horty i biskupa Carlosa Ximenesa w grudniu 1996 r. Żadnej aktywności nie wykazywała również powołana pod parasolem ASEAN główna struktura odpowiedzialna od połowy lat 90. XX w. za kwestie bezpieczeństwa ponadregionalnego w obszarze Azji i Pacyfiku, czyli ARF. W kontrze do tych zachowań wystąpiły demokratyczne prądy, coraz silniej odczuwalne w wewnętrznym dyskursie politycznym takich państw, jak Filipiny czy Tajlandia, które pozwoliły na większą otwartość i elastyczność debaty wokół tematu Timoru, z czego korzystały pozarządowe organizacje pokroju Konferencji Azji-Pacyfiku w Sprawie Timoru Wschodniego [Ortuoste 2011]. Nie gasły również ambicje samych Timoryjczyków, które potwierdził w swojej mowie 
dziękczynnej przed komitetem noblowskim przyszły prezydent Ramos-Horta (2007-2012). Stwierdził w niej, że jego bracia są w pełni świadomi swojej przynależności kulturowej i po odzyskaniu niepodległości będą dążyli do zasilenia struktur ASEAN [Joseph, Hamaguchi 2014].

Pomimo rosnącej presji zewnętrznej głównym imperatywem polityki zagranicznej uczestników ASEAN pozostało powstrzymywanie się od ingerencji w wewnętrzne sprawy postrzeganej od początku tego procesu za blokowego lidera Indonezji. Randze tego zobowiązania sprzyjał fakt, że to właśnie indonezyjska agresja w ramach konfrontasi $i^{2}$ stanowiła niegdyś największą przeszkodę w wykształceniu regionalnej organizacji, dlatego poprawne stosunki z Dżakartą odbierano jako szczególnie cenną spuściznę historii [Dupont 2003]. Wśród innych, równie istotnych przesłanek, wymieniano m.in. widmo „bałkanizacji Indonezji”, w przypadku której następstwa azjatyckiego kryzysu finansowego z lat 1997-1998 w połączeniu z separatystycznym impulsem płynącym z Timoru mogłyby się okazać pretekstem do dalszej dezintegracji państwa i odłączenia się od niego na zasadzie secesji kolejnych z odmiennych etnicznie bądź religijnie prowincji. Tego rodzaju scenariusz oznaczałby postawienie dalszej egzystencji całego ASEAN pod znakiem zapytania [Dupont 2000].

Po ustąpieniu z urzędu Suharto sytuacja wewnętrzna oraz naciski ONZ skłoniły nowego prezydenta Indonezji Jusufa Habibiego do zmiany kursu wobec coraz bardziej ciążącej budżetowi i wizerunkowi kraju prowincji. Szef państwa wyraził zgodę na przeprowadzenie referendum niepodległościowego i pozwolił w $1999 \mathrm{r}$. na rozmieszczenie na terytorium Timoru misji wojskowej INTERFET (International Force for East Timor), która przygotowała grunt pod obecność Tymczasowej Administracji ONZ w Timorze Wschodnim w latach 1999-2002. Decyzja ta wyznaczyła cezurę w relacjach na linii ASEAN-Timor Wschodni. Zmiana podejścia regionalnego hegemona w połączeniu z obawami o rosnące wpływy stanowiących trzon operacji ONZ żołnierzy australijskich skłoniły stowarzyszenie do wzięcia udziału w obu misjach międzynarodowych. Początkowa niechęć szybko przerodziła się w wymierne wsparcie wojskowo-techniczne, a niemal $25 \%$ wszystkich zaangażowanych członków personelu międzynarodowego pochodziło z krajów ASEAN [Narine 2002]. Interwencja na Timorze ponownie wznieciła debatę o tym, jak adekwatne względem wymogów bieżącej integracji w Azji Południowo-Wschodniej pozostają sztywne normy i zasady, którymi ASEAN kieruje się w swojej polityce. Dyskusja spowodowała do pewnego stopnia rozłam pomiędzy bardziej liberalnie usposobionymi państwami pokroju Filipin czy Tajlandii oraz autorytarnymi rządami w Mjanmie i Wietnamie.

Odzyskanie niepodległości przez Timor Wschodni w dniu 20 maja 2002 r. być może nie przyczyniło się do rewolucji w azjatyckich stosunkach regionalnych w postaci zasadniczych implikacji dla regionalnej gospodarki czy systemu

2 Termin konfrontasi odnosi się do zbrojnego konfliktu o przyszłość wyspy Borneo prowadzonego w latach 1963-1966 pomiędzy Indonezją a Malezją. 
bezpieczeństwa, jednak poważnie zmieniło optykę wśród krajów przynależnych do ASEAN. Wzorem dzisiejszych Niemiec, których polityka zagraniczna w odniesieniu do wybranych państw często jest łączona z pojęciem spłaty długu za zbrodnie III Rzeszy, Indonezja postawiła na analogiczny model współpracy z nowymi elitami timoryjskimi, stając się gorącym zwolennikiem przystąpienia najbiedniejszego kraju Azji do ASEAN. Postawę władz w Dżakarcie wzmocniło obecne od początku istnienia wspólnoty ideologiczne przekonanie, że celem ostatecznym istnienia forum jest skupienie w swoich strukturach wszystkich krajów regionu w imię wizji ,jednej Azji Południowo-Wschodniej” [Kin Wah 1997]. Siła tej koncepcji, jak pokazał przypadek akcesji obszaru CLMV, potrafiła skutecznie przeciwstawić się dużo bardziej pragmatycznym przesłankom natury politycznej bądź gospodarczej.

Ponowne zaistnienie Timoru Wschodniego na mapie Azji automatycznie skutkowało aktualizacją doktryny, która wydawała się już w pełni zrealizowana wraz z ostatnim rozszerzeniem ASEAN pod koniec XX wieku. Jeszcze przed przekazaniem obowiązków administracyjnych przez ONZ w ręce nowo wybranych władz Dili stanęło przed dylematem związanym z określeniem pryncypiów polityki zagranicznej, za jakimi zamierza podążać. Wybór sprowadzał się do identyfikacji własnej tożsamości, która zgodnie ze słowami Ramosa-Horty znajdowała się na przecięciu trzech odrębnych cywilizacji - odwołującej się do dziedzictwa wysp Pacyfiku kultury melanezyjskiej, kojarzonej z Azją Południowo-Wschodnią spuścizny malajsko-polinezyjskiej oraz łacińsko-katolickich znamion okresu kolonialnego [Sahin 2014]. Timoryjski parlament poparł ostatecznie dążenia do ustanowienia szczególnych relacji z ASEAN, opowiadając się tym samym za przynależnością do regionu Azji Południowo-Wschodniej. Potencjalne przystąpienie do organizacji miało gwarantować państwu nie tyle ekonomiczną stabilność i szanse rozwojowe, co w owym czasie stanowiło modus vivendi ugrupowania, lecz przede wszystkim miało wzmocnić gwarancje bezpieczeństwa [Ramos-Horta 2001].

W roku 2002, zaledwie kilka miesięcy po ustabilizowaniu sytuacji wewnętrznej, Timor Wschodni został uznany za specjalnego obserwatora wewnątrz ASEAN i dopuszczony jako gość do sesji otwartych Szczytu ASEAN oraz wybranych obrad ministerialnych. Z punktu widzenia dyplomacji był to ogromny sukces, biorąc pod uwagę tempo, $w$ jakim udało się zrealizować ten cel oraz przyszłościowe konsekwencje tej decyzji. W 1983 r. wielka piątka założycieli ASEAN ustaliła, że status obserwatora będzie nadawany jedynie tym państwom, które są geograficznie częścią obszaru Azji Południowo-Wschodniej, spełniają kryteria umożliwiające im dołączenie do grona uczestników procesów integracyjnych, a w przyszłości najprawdopodobniej uzyskają członkostwo [Severino 2006]. Decyzja o podniesieniu rangi Timoru, podjęta nie bez wewnętrznych sporów i dyskusji, nałożyła na kraje ASEAN swoiste zobowiązanie rozszerzenia organizacji o jedenastego członka w bliżej nieokreślonej przyszłości. Przynajmniej taka interpretacja panowała wtedy w Dili. Niemniej jednak brak znaczącej ewolucji 
w postępach procesu akcesyjnego w kolejnych latach wskazuje, że konsensus wokół powyższej rezolucji zbudowano na niezwykle kruchych i niepewnych fundamentach, a niektórzy szefowie rządów ASEAN odczuwają poważne wątpliwości w związku z wystosowanymi kolektywnie pod adresem państwa zapewnieniami. Innym elementem, który nie stanowi w tym wymiarze optymistycznej przesłanki, jest kazus Papui Nowej Gwinei. Kraj ten posiada oficjalny status obserwatora już od 1976 r., lecz nadal pozostaje poza kręgiem organizacji, a jego uprawnienia są ograniczone do brania udziału w wydarzeniach rangi ceremonialnej i okazjonalnych konsultacjach z pozostałymi partnerami [Thuzar 2017].

Dopełnienie procesu instytucjonalizacji współpracy z ASEAN dokonało się przez dołączenie Timoru Wschodniego do ARF w 2005 r. oraz podpisanie dwa lata później Traktatu o Przyjaźni i Współpracy w Azji Południowo-Wschodniej, co oznaczało przyjęcie przez kraj zasad funkcjonowania, norm prawnych oraz metod postępowania wypracowanych na bazie dotychczasowej ścieżki integracyjnej organizacji. Ten kolejny krok milowy odebrano na świecie jako rodzaj gwarancji zwiastującej rychłe poszerzenie ASEAN. Tuż po podpisaniu dokumentu Sekretariat w Dżakarcie wydał jednak oświadczenie, w którym zasugerował pięcioletni okres przejściowy pomiędzy ratyfikacją Traktatu a możliwym przystąpieniem przez Timor do struktur ASEAN. Funkcjonariusze powołali się na konieczność dostosowania polityki Dili do wymogów prawnych Strefy Wolnego Handlu ASEAN oraz spodziewane ogólne koszty akcesyjne, chociaż równie istotne pozostały nieoficjalnie wymieniane czynniki, takie jak problem bilateralnych relacji z Indonezją w odniesieniu do kwestii osądzenia sprawców ludobójstwa z czasów okupacji czy relokacja na terytorium kraju uchodźców politycznych z sąsiedniej Papui Nowej Gwinei [Paul 2010]. W międzyczasie, ku dalszemu rozczarowaniu władz Timoru Wschodniego, Sekretariat przekazał w opublikowanym przez siebie biuletynie, że członkostwo państwa w ARF oraz status obserwatora w ASEAN nie tworzą żadnych specjalnych praw dla Dili wewnątrz ugrupowania i nie są jednoznaczne z pozytywnym rozpatrzeniem ewentualnego wniosku o przystąpienie do forum [Kyodo News International 2006].

W roku 2009 władze Timoru Wschodniego przy pomocy środków finansowych pozyskanych od rządu Korei Południowej dokonały otwarcia Narodowego Sekretariatu ASEAN, ponieważ analogiczne jednostki funkcjonują w każdym z państw członkowskich jako punkty kontaktu z Sekretariatem ASEAN w Dżakarcie. Głównym zadaniem placówki stało się przygotowanie timoryjskich kadr do objęcia w przyszłości ważnych stanowisk w administracji rządowej odpowiedzialnej za utrzymywanie stosunków z ASEAN [ASEAN Secretariat 2009]. Prezydent Ramos-Horta podczas inauguracji wyraził nadzieję na jak najszybsze przystąpienie państwa do wspólnoty, po raz pierwszy prezentując opinii publicznej trzy podstawowe czynniki determinujące proakcesyjną postawę jego państwa względem organizacji - bliskość geograficzną, społeczne poparcie dla projektu integracji oraz jasną i przewidywalną politykę rządu [Fernandes, Soares 2017]. W marcu 2011 r. minister spraw zagranicznych Zacarias da Costa, wykorzystując 
fakt przewodniczenia Szczytowi ASEAN przez Indonezję, oficjalnie przekazał aplikację członkowską Timoru z nadzieją, że cała procedura może zakończyć się powodzeniem jeszcze w bieżącym roku [Shoesmith 2011]. Wizja ta okazała się jednak nierealistyczna. W latach 2012-2013 zorganizowano w Dili wiele pomniejszych spotkań w ramach szerokiej agendy wydarzeń sygnowanych logo ASEAN. Wśród nich znalazły się m.in. Regionalne Forum Misji Obserwatorów Wyborczych ASEAN czy też Antykorupcyjna Inicjatywa Azji i Pacyfiku. W tym samym czasie minister da Costa podjął swoistą pielgrzymkę dyplomatyczną do wszystkich dziesięciu członków ASEAN, aby uzyskać ich gwarancje oraz lobbować za dalszym poparciem [Hunt 2016]. Do końca 2014 r. udało się również sfinalizować proces ustanawiania ambasad we wszystkich stolicach ASEAN, co stanowiło nieformalny wymóg postawiony przez państwa wspólnoty.

\section{OCENA STATUSU TIMORU WSCHODNIEGO JAKO POTENCJALNEGO CZLONKA ORGANIZACJI}

Podstawowe problemy związane z ewentualną akcesją Timoru Wschodniego do ASEAN można podzielić na dwie kategorie. W pierwszej znajdują się obiektywne czynniki natury politycznej, gospodarczej czy społecznej, wśród których zidentyfikowane braki wynikają z wciąż nieustabilizowanych w wystarczającym stopniu struktur timoryjskiej państwowości. Druga grupa obejmuje nie mniej istotny kontekst historyczny, rozwój relacji z pozostałymi członkami stowarzyszenia, a także dodatkowe uprzedzenia żywione względem najmłodszego państwa Azji. Obecnie najczęściej podnoszonym argumentem wysuwanym przeciwko Timorowi jest jego instytucjonalno-infrastrukturalna niewydolność oraz brak zasobów ludzkich zdolnych sprostać wymogom odnoszącym się do członkostwa w tak złożonej organizacji, jaką pozostaje ASEAN. Zarzut ten w wyraźny sposób został podniesiony bezpośrednio po złożeniu oficjalnej aplikacji członkowskiej w 2011 r., a szczególnie krytyczne stanowisko w sprawie przejawia do czasów współczesnych Singapur. W listopadzie tego samego roku tamtejsi dyplomaci zainicjowali działanie wstępnej grupy roboczej, która zajęła się weryfikacją kandydatury Timoru z punktu widzenia wymogów stawianych potencjalnym członkom w artykule VI Karty ASEAN z 2008 r. W toku prac ciała ustalono, że kraj nie posiada odpowiednio dużego personelu, żeby rozdysponować go pomiędzy niemal tysiąc spotkań organizowanych dorocznie w ramach agendy ASEAN [Kennes 2015]. Wątpliwości budziło też zasadnicze przygotowanie służby zagranicznej i jej podstawowe zaniedbania oraz brak wiedzy pokroju nieznajomości etykiety dyplomatycznej oraz języka angielskiego, który pozostaje oficjalnym językiem ugrupowania [Sahin 2012].

Kwestia niedoborów kadrowych jest obecnie prawdopodobnie jedynym punktem krytyki, co do którego władze Timoru zgadzają się z jej autorami. W 2014 r. wyraźnie mówił o tym ówczesny minister spraw zagranicznych José 
Luís Guterres, zaznaczając przy tym, że ze względu na zgromadzone przez państwo fundusze pochodzące $\mathrm{z}$ wydobycia ropy naftowej możliwym rozwiązaniem tej sytuacji byłoby zatrudnienie obcych ekspertów w roli miejscowych dyplomatów [Gutteres 2012]. Ten oryginalny pomysł nie powinien jednak hamować kształcenia państwowych urzędników. Skupienie się na politycznych najemnikach może skutkować utratą części kontroli nad suwerennością działań na arenie międzynarodowej oraz prowadzić do różnego rodzaju konfliktów interesów, szczególnie kiedy zatrudnieni funkcjonariusze będą pochodzenia indonezyjskiego. W tym wypadku dużego znaczenia nabiera uruchomiony w 2011 r. Fundusz Rozwoju Kapitału Ludzkiego. Niemal $200 \mathrm{mln}$ dolarów przeznaczonych na jego aktywność w pierwszych pięciu latach ma zapewnić do $2030 \mathrm{r}$. odpowiedni pułap wykwalifikowanych specjalistów, również tych z pogranicza nauk politycznych i społecznych [The Government of Timor Leste 2011]. Jak alarmująco zauważyła Jacqueline Aquino Siapno, długofalowa strategia edukacyjna jest konieczna, ponieważ obecnie kraj cierpi na znaczący deficyt wiedzy. Miejscowi pracownicy naukowi oraz studenci nie mogą pozwolić sobie na wyjazdy zagraniczne oraz nie posiadają bazowego dostępu do narzędzi naukowych czy specjalistycznych publikacji. Powoduje to postępujące obumieranie zainteresowania Timoryjczyków światem zewnętrznym, podczas gdy inne narodowości ASEAN zaczynają postrzegać ich jako obcych i wyalienowanych z procesów regionalizacji [Aquino Siapno 2014].

Od początku istnienia jako niepodległe państwo Timor Wschodni wydał ponad 2 mld dolarów na rozwój miejscowej infrastruktury oraz pozyskał liczne środki rozwojowe z takich instytucji, jak Bank Światowy czy Azjatycki Bank Rozwoju. Pomimo tych nakładów państwo wciąż boryka się z elementarnymi brakami w dziedzinie transportu, energetyki czy usług socjalnych. Wyrazem tego stanu rzeczy jest dopiero 133 miejsce w rankingu World Economic Forum badającym rozwój infrastrukturalny krajów. Niezależnie od faktu, że rząd wydaje prawie połowę rocznych przychodów budżetowych na rozwój infrastruktury, perspektywa zorganizowania w stolicy Dili jednego z kolejnych szczytów ASEAN oddala się wraz ze szczegółowym przestudiowaniem warunków, które miałyby towarzyszyć wizytom delegatów. Mowa tu przede wszystkim o stanie lokalnych dróg, częstych przerwach w dostawach prądu, braku odpowiednich pomieszczeń mogących gościć przedstawicieli czy w końcu zbyt kameralnym lotnisku, które nie byłoby w stanie obsłużyć dużej intensywności połączeń lotniczych i samolotów o określonych gabarytach [Horta 2013]. Wątpliwości wśród zajmujących się oceną statusu Timoru dyplomatów ASEAN budziło też znaczne niedoinwestowanie kluczowych z punktu widzenia prawidłowego rozwoju społeczeństwa sektorów zdrowia i edukacji. Ich łączne finansowanie nie przekraczało w $2011 \mathrm{r}$. poziomu $15 \%$, podczas gdy średnia w państwach rozwijających się, do grona których Timor od początku aspiruje, sięga ponad 30\% [Scheiner 2015].

Czerpanie wiedzy na temat stanu państwa $\mathrm{z}$ dostępnych statystyk przynosi dalsze znaki zapytania. Gospodarka kraju po przyłączeniu do ASEAN miałaby wielkość zaledwie 15\% najsłabszej obecnie gospodarki ugrupowania, czyli Laosu. 
Podobnie jak ma to miejsce w przypadku Brunei, jest ona całkowicie uzależniona od popytu i zysków pochodzących ze sprzedaży ropy naftowej. W 2015 r. projekt dochodów budżetowych przewidywał 2,4 mld dolarów zysku pochodzących $z$ handlu paliwem i produktami pochodnymi, natomiast inne źródła finansowania oszacowano na zaledwie $170 \mathrm{mln}$, w tym $70 \mathrm{mln}$ stanowiły przyznane już przez społeczność międzynarodową pożyczki [Scheiner 2015]. Monokultura surowcowa skłoniła w 2005 r. władze do ustanowienia specjalnego funduszu, który na wzór podobnych instrumentów istniejących w Norwegii czy też państwach Półwyspu Arabskiego ma za zadanie zgromadzić ponad 5 mld dolarów w ramach zysków wypracowanych przez eksport ropy w ciągu najbliższych dwudziestu lat [Financial Times 2005]. Istnieją jednak poważne obawy co do tego, w jakim stopniu i jak długo Timor Wschodni jest w stanie polegać na swoich zasobach. Niektórzy analitycy wskazują, że złoża wyczerpią się w perspektywie najbliższej dekady, co wpędziłoby rozwijający się w ostatniej dekadzie w średnim tempie 8,5\% kraj w niewyobrażalny kryzys [Hamutuk 2015]. Dostęp do wartych $40 \mathrm{mld}$ dolarów pól naftowych Greater Sunrise jest problematyczny z przyczyn natury technicznej, a dodatkowe utrudnienie stanowi ciągnący się od lat zatarg o te terytoria z Australią [Wyeth 2016]. Ulokowane na dnie szelfu kontynentalnego złoża stały się już przedmiotem sporu przed Trybunałem Arbitrażowym w Hadze, a cała sprawa dodatkowo komplikuje Timorowi porozumienie z ASEAN, jako że dla organizacji niezwykle istotne pozostają przyjazne stosunki z Australią jako naturalnym sąsiadem regionu.

Niejednoznaczną w ocenie sytuację gospodarczą Timor stara się balansować przez kreowanie się na państwo stabilne politycznie i nowoczesne. Założone jako stowarzyszenie dbające o regionalny ład i bezpieczeństwo ASEAN nadal przywiązuje kluczową wagę do pierwszego filara integracji w ramach Wspólnoty Politycznej i Bezpieczeństwa. W tym kontekście niezwykle ważne staje się zapewnienie porządku w przestrzeni publicznej oraz gwarancja, że Timor Wschodni nie popadnie w wewnętrzny konflikt, stając się źródłem regionalnych niepokojów. Niektórzy nadal wypominają mu polityczno-wojskowy kryzys z 2006 r., jednak od tego czasu wyspą nie wstrząsnęły żadne istotne incydenty z użyciem przemocy, a od 2012 r. nie przebywają już na jego terytorium żołnierze misji stabilizacyjnej ONZ. W maju 2018 r. udało się także przełamać polityczny impas związany z wynikami poprzedniej elekcji, w czasie trwania której wskutek braku zdecydowanych rozstrzygnięć u władzy rząd mniejszościowy przez okres dziesięciu miesięcy pozostawał nieefektywny w swoich decyzjach [Neves 2018]. Timor to jednocześnie prężny członek światowej wspólnoty demokratycznej, a odbywające się zgodnie z terminami wybory prezydenckie i parlamentarne przebiegają bez zakłóceń, wyłaniając borykające się z rozmaitymi problemami, lecz stabilne rządy. Polityczni liderzy, przez lata skłóceni, potrafią przy tym budować szersze fronty porozumienia i współpracować z opozycją. Liberalny wizerunek wzmacniają wolne od cenzury media, rzadko spotykany w tych stronach globu całkowity zakaz kary śmierci czy rekordowy w skali kontynentu udział kobiet 
w parlamencie [Rosenthal 2015]. W konsekwencji w 2016 r. Timor Wschodni znalazł się na pierwszym miejscu wśród wszystkich państw Azji Południowej Wschodniej w rankingu Democracy Index autorstwa Economist Intelligence Unit [Minister of State..., 2016].

Budujące z perspektywy zachodniego obserwatora sukcesy mogą paradoksalnie nie stanowić silnej karty przetargowej na forum państw, dla których transparentność procesów politycznych oraz kwestie praw człowieka nigdy nie stanowiły priorytetu. ASEAN to organizacja międzyrządowa, ufundowana na zasadach pełnej niezależności jej członków, a co za tym idzie obojętna wobec systemów, w ramach których poszczególne kraje funkcjonują jako jej stabilne ogniwa. Potwierdza to obecność w ugrupowaniu aktorów o mocno wątpliwym rodowodzie demokratycznym. Wśród nich znajdują się komunistyczne Laos i Wietnam oraz częściowo autorytarne Kambodża, Mjanma, a nawet Singapur, jedyny kraj ASEAN, który oprócz zdecydowanej kampanii punktującej wady kandydatury Dili znacząco zmniejszył na wyspie wielkość swoich inwestycji w ostatniej dekadzie [Sahin 2012]. Zaakceptowanie kandydatury starającego się jak dotąd skutecznie imitować rozwiązania liberalnych demokracji euroatlantyckich Timoru Wschodniego mogłoby oznaczać pojawienie się wewnątrz ASEAN niekompatybilnego z jego dotychczas ugruntowanymi zasadami dyskursu. Wymienione państwa oficjalnie popierają dążenia Timoru, jednak ich zakulisowa optyka może odbiegać od formułowanych w obecności tamtejszych delegacji deklaracji [Talesco 2016]. Mjanma pozostaje wyczulona na komentarze Dili w sprawie pogromów czynionych na muzułmańskiej mniejszości Rohingya oraz prezentowane w przeszłości krytyczne i częściowo nonszalanckie oceny partycypacji tego państwa w strukturach ugrupowania. Innym czynnikiem antagonizującym, szczególnie w ocenie mającej wciąż istotny wpływ na losy kraju junty wojskowej, jest także bliska współpraca timoryjskiej i birmańskiej opozycji w latach 90. XX w., co wcześniej skłoniło Naypyidaw do opowiedzenia się przeciwko przyznaniu Dili statusu obserwatora [East Timor Law \& Justice Bulletin 2017]. Z kolei bodźcem antagonizującym Laos stało się w ostatnim czasie przejęcie przez Timor części jego obowiązków wynikających z przysługującego Wientianowi w 2016 r. rotacyjnego przywództwa w organizacji. Niezdolność do logistycznej obsługi zaplanowanych spotkań agendy ASEAN skutkowała przeniesieniem kilku z nich (m.in. Forum Ludności ASEAN) na wschodnią część Timoru. Ten zawstydzający dla Laosu epizod udowodnił jednocześnie, że Timor Wschodni jest w stanie zmobilizować odpowiednie środki i podołać wyzwaniom związanym z przyjęciem na siebie roli kraju gospodarza.

Niezależnie od ogólnego bilansu zysków i strat mierzonych określonymi wskaźnikami ekonomicznymi czy też interesami zaangażowanych stron decyzja o przyjęciu Timoru Wschodniego w struktury ASEAN powinna wynikać z konsensusu pomiędzy aktualnymi członkami ugrupowania. W 2008 r. w Karcie ASEAN pojawily się po raz pierwszy szeroko zdefiniowane kryteria, które pozostają podstawą rozpatrywania wniosków akcesyjnych, niemniej jednak ich 
interpretacja zdaje się być do pewnego stopnia czymś uznaniowym [Thuzar 2017]. Timor spełnia obecnie trzy z czterech zidentyfikowanych przesłanek: geograficznie przynależy do Azji Południowo-Wschodniej, został uznany przez wszystkie państwa regionu, a także zobowiązywał się do przyjęcia aksjologii ujętej w Karcie ASEAN. Problematyczny pozostaje ostatni wymóg, czyli chęć i zdolności do wypełniania zobowiązań ciążących na kraju stowarzyszonym. O ile nie ma podstaw, żeby wątpić w dobrą wolę samego Timoru, to jednak istnieją rozbieżności w związku z oceną jego potencjału w przypadku takich czynności, jak stałe wpłaty na rzecz Funduszu Rozwoju ASEAN, równa partycypacja w budżecie organizacji czy przede wszystkim realizacja mechanizmów umożliwiających adaptację polityki Strefy Wolnego Handlu ASEAN. Ostatni z tych czynników jest kluczowy m.in. ze względu na rosnące znaczenie projektu AEC, która od momentu powstania w grudniu 2015 r. stała się głównym motorem napędowym regionu i jego najlepszą wizytówką z dumą pokazywaną przedstawicielom świata zewnętrznego.

Obawy dotyczące skutecznej implementacji rozwiązań prawnych przez Timor, a następnie jego wątpliwa konkurencyjność w ramach AEC to dzisiaj największe zmartwienia Sekretariatu w Dżakarcie. Szefowie rządów za wszelką cenę chcieliby uniknąć rozszerzenia o państwo roszczeniowe, gdzie wielomilionowe inwestycje stałyby się koniecznością w celu pokrycia luki rozwojowej dzielącej Dili od poprzednich generacji. Odpierając zarzuty, politycy timoryjscy powołują się na fakt, że kraj nie jest obecnie niczyim dłużnikiem, a ich dążenie do ASEAN wynika w przeważającej mierze z pobudek tożsamościowych i strategii bezpieczeństwa. Wsparcia w tej narracji udziela im strona indonezyjska. Tamtejszy minister spraw zagranicznych wyraził przekonanie, że bogactwa naturalne kraju spowodują, że nie tylko nie będzie on wymagał dopłat ze wspólnej kasy, ale wręcz stanie się w przyszłości jednym z płatników netto [Ali 2011]. Niejednoznaczne sądy w łonie samej organizacji zdają się prowadzić do wniosku, że część państw kieruje się w swoim postępowaniu wobec Timoru uprzedzeniami wynikającymi z pamięci historycznej oraz błędów, jakie popełniono w latach 90. XX w., kiedy ASEAN powiększył się o grupę CLMV. Jej wchłonięcie wymusiło czasowe zahamowanie części procesów integracyjnych (m.in. opóźnienie tworzenia Strefy Wolnego Handlu ASEAN), a także zobligowało organizację do utworzenia specjalnych i kosztownych instrumentów (np. Inicjatywy na Rzecz Rozwoju ASEAN) ukierunkowanych na wsparcie zapóźnionych gospodarek. Efekty tych starań można po latach oceniać różnie, a dodatkową gorycz wywołuje w kuluarach rosnąca polityczno-gospodarcza zależność Kambodży czy też Mjanmy od Chin, która chociażby w związku z wydarzeniami na Morzu Południowochińskim wyraźnie osłabiła solidarność ugrupowania.

Spowodowany takim myśleniem strach przed ekspansją nie pozwala dostrzec sukcesów, jakie stały się udziałem rządu w Dili w ciągu ostatnich piętnastu lat. Wśród tych osiągnięć znajdują się m.in. wyższy niż u większości państw CLMV wskaźnik Human Development Index, stały wzrost gospodarczy, dwukrotne zwiększenie PKB na głowę mieszkańca, likwidacja analfabetyzmu oraz skuteczna implementacja rozwiązań prawnych $\mathrm{w}$ walce $\mathrm{z}$ korupcją czy też łamaniem praw człowieka 
[Ramos-Horta 2011]. Timor Wschodni zdołał przy tym uregulować niespokojną sytuację wewnętrzną, zwalczając przestępczość zorganizowaną, ograniczając wskaźniki przestępczości oraz wygaszając konflikty wynikające z etniczno-religijnego czy ideologicznego zróżnicowania osób zamieszkujących wyspę [The Asia Foundation 2017]. Z kolei w odniesieniu do polityki zewnętrznej młode państwo dało się poznać jako rzetelny partner i aktywny uczestnik licznych projektów międzynarodowych, dzięki którym zdobyło niezbędne doświadczenie na tej płaszczyźnie. Szczególną uwagę należy zwrócić na ugrupowanie G7+. Forum to skupia kilkadziesiąt państw świata dotkniętych w przeszłości wyniszczającymi konfliktami, a Timor pełni w nim nieformalne przywództwo, użyczając miejsca sekretariatowi organizacji. Program polityki zagranicznej znany pod nazwą „Acting West, Looking East” umożliwia pełnienie przez Timor roli łącznika pomiędzy szeregiem mniejszych wspólnot rejonu Azji i Pacyfiku oraz Wspólnotą Państw Portugalskojęzycznych (Comunidade dos Países de Língua Portuguesa - CPLP) [Sousa-Santos 2015]. Można wysunąć przypuszczenie, że przystąpienie do ASEAN umożliwiłoby pogłębienie tej kooperacji i gwarancję jeszcze donioślejszej roli dla stanowiącego najdalej wysunięte na wschód ogniwo CPLP państwa.

W połowie 2018 r. kandydatura Timoru Wschodniego do struktur ASEAN wciąż pozostaje nierozstrzygnięta. Podczas wieńczących obchody jubileuszu 50-lecia wspólnoty spotkań dyplomatów, mających miejsce w listopadzie i grudniu 2017 r. w Manili, dwukrotnie zdecydowano o odroczeniu wszelkich działań zmierzających do poszerzenia ugrupowania o jedenastego członka [ABS CBN News 2017]. Perspektywa rozbudowy ASEAN została w ten sposób odsunięta w czasie prawdopodobnie na koniec bądź też początek kolejnej dekady. Należy mieć bowiem na uwadze fakt, że obecnie szefujący ASEAN Singapur potwierdził swoje wcześniejsze zastrzeżenia wobec możliwości akceptacji aplikacji Timoru na przestrzeni najbliższych miesięcy, pomimo zapewnień o kontynuowaniu procesu dalszych konsultacji i analiz przez wyspecjalizowane w tym celu grupy robocze (MetroTV News, 2018).

\section{WNIOSKI}

Potencjalne korzyści wynikające z członkostwa Timoru Wschodniego w ASEAN wykraczają daleko poza aspekt wizerunkowy, który niewątpliwie zostałby wzmocniony związkiem z tak doświadczonym burzliwą historią państwem. Jego obecność na forum przyczyniłaby się do ożywienia debaty wokół postulatów demokratyzacji stowarzyszenia oraz wyczulenia go na kwestie praw człowieka. Obecnie istniejące mechanizmy oraz instytucje powstałe na mocy zapisów Karty ASEAN nie są na tym polu zbyt skuteczne i brakuje im niezależności względem państw [Robertson 2012]. Głos mieszkańców wyspy wpisałby się w rosnące potrzeby coraz liczniejszej i lepiej wykształconej klasy średniej zamieszkującej Azję Południowo--Wschodnią, dla której wolności obywatelskie nabierają wraz z bo- 
gaceniem się społeczeństw i postępem technologicznym szczególnego znaczenia. Drugą areną wpływu pozostaje szeroko pojęte bezpieczeństwo. Przystąpienie do struktur ASEAN praktycznie zniwelowałoby groźbę uwikłania państwa w międzynarodowy konflikt bądź wystąpienia wewnętrznej rebelii. Żaden z lokalnych aktorów nie chciałby, żeby w Dili na nowo wytworzyła się sytuacja zagrożenia, która mogłaby promieniować na okoliczne tereny. Destabilizacja tak kruchego podmiotu, jakim wciąż jeszcze jest Timor Wschodni, nie jest jedynie założeniem czysto hipotetycznym. Polityczne napięcia wśród przywódców bądź nawet chwilowe załamanie gospodarcze mogą wzniecić dostatecznie silną iskrę. Sygnałem ostrzegawczym do zaistnienia takich okoliczności był niedawny kryzys parlamentarny, kiedy Timor Wschodni niemal przez rok nie miał zatwierdzonego budżetu, co doprowadziło państwo na skraj paraliżu [Hutt 2018]. Rolą ASEAN jest niedopuszczenie do wystąpienia punktów zapalnych przez skutecznie skorelowanie ze sobą interesów obu stron, co w dłuższej perspektywie oferuje jedynie pełna integracja.

Timor Wschodni zdołał na przestrzeni ostatnich lat uzyskać pełne poparcie dyplomatyczne dla swoich ambicji. Wysocy funkcjonariusze z dziesięciu stolic ASEAN oraz najważniejsi gracze Azji Wschodniej i Pacyfiku na czele z Chinami, Japonią czy Australią także odnoszą się w przychylny sposób do idei rozszerzenia gremium. Począwszy od 2013 r., Rada Koordynacyjna ASEAN ustanowiła trzy odrębne grupy robocze złożone z ekspertów uniwersyteckich z Australii, Malezji i Singapuru, których zadaniem jest wnikliwe przestudiowanie warunków panujących w Timorze oraz ocena wpływu ewentualnego członkostwa kraju na procesy polityczne, gospodarcze i społeczne wewnątrz ugrupowania [Chalermpalanupap 2015]. To od ich pracy w dużej mierze zależą ostateczne rekomendacje i losy złożonej kandydatury. Niestety z perspektywy społeczeństwa Timoru dane zebrane przez poszczególne ośrodki badawcze nie zostały nigdy upublicznione, chociaż z pierwotnych założeń wynikało, że do 2017 r. ewaluacja zostanie zakończona. Nie wiadomo nawet, czy same władze Timoru zapoznały się z opracowaniami. Aura tajemniczości spowija również dokumenty strategiczne ASEAN oraz wszelkiego rodzaju komunikaty pokonferencyjne, w czym wtórują im niechętni do szczegółowych rozmów politycy. Wątek timoryjski jest wyraźnie marginalizowany, poruszany jedynie symbolicznie bądź całkowicie pomijany.

Ten stan zawieszenia nie oznacza jednak, że Timor funkcjonuje dzisiaj w zupełnej próżni. Nieodłącznym konkurentem ASEAN w walce o serca i umysły Timoryjczyków pozostają Chiny, które jako pierwsze państwo na świecie uznały niepodległość kraju; jeszcze w maju 2002 r. ustanowiły z nim stosunki bilateralne [Sahin 2010]. Na przestrzeni ostatnich lat wzajemne kontakty uległy dalszej dynamizacji, czego przykładem mogą być imponujące inwestycje chińskich przedsiębiorstw. Pomoc rozwojowa Pekinu sięgnęła w ostatnim pięcioleciu 77 mln dolarów, jednak cena ta nie wydaje się szczególnie wygórowana, jeżeli wziąć pod uwagę fakt, że tamtejsze firmy budowlane zabezpieczyły dla siebie kontrakty na sumę 525 mln dolarów [Hutt 2016]. Za pozyskane z Banku Chin pożyczki w Dili powstał m.in. nowy pałac prezydencki, kompleks budowli słu- 
żących celom bezpieczeństwa narodowego, a także siedziba Ministerstwa Spraw Zagranicznych [The Habicie Center 2016]. Pokazuje to dobitnie, że Chińczycy zdobyli duże zaufanie wśród miejscowych elit, nie ograniczając swoich projektów infrastrukturalnych jedynie do sektora turystycznego bądź wydobywczego, lecz angażując się pośrednio w zapewnienie - dosłownie i w przenośni - stabilnych fundamentów dla sfery politycznej.

Liderzy ASEAN powinni pamiętać, że już w 2004 r. Ramos-Horta ostrzegł delegatów zgromadzonych na Szczycie Ministerialnym w Wientianie, że jego kraj „może w bliskiej przyszłości nawiązać bliższe relacje z innymi państwami, co prawdopodobnie stanowiłoby powód zdenerwowania wspólnoty" [Severino 2006]. Remedium na te zawoalowane naciski dotyczące bardziej aktywnego stanowiska bloku stało się wejście Timoru Wschodniego do ARF w czerwcu 2005 r., jednak obecnie stowarzyszenie nie dysponuje już środkami zastępczymi, które skuteczniej niż sama decyzja akcesyjna wpłynęłyby na zatrzymanie ciążenia wschodniej części wyspy w kierunku takich podmiotów jak Chiny. Scenariusz ten jest tym bardziej prawdopodobny, jeżeli weźmie się pod uwagę entuzjastyczne nastawienie Dili wobec koncepcji „One Belt, One Road” w jej morskiej odnodze znanej jako „21st Century Maritime Silkroad” i roztaczające się z tego tytułu perspektywy dla rozwoju pobliskiego rejonu [Go China 2015]. Obietnica ożywienia handlu morskiego połączona z planami rozbudowy portu w Dili stanowią wystarczający bodziec, podobnie jak nadzieje na zacieśnienie więzów z luzofońskimi państwami Afryki za sprawą partycypacji w rozbudowie światowych szlaków oceanicznych.

W ocenie rządzącej dotychczas partii FRETILIN oraz nowo wybranej koalicji w ramach bloku AMP (Alliance for Change and Progress) przyjazne i produktywne relacje bilateralne ze stroną chińską dostarczają nie tylko potrzebnego dla unowocześnienia państwa kapitału, ale stanowią śmiały manifest wobec partnerów z ASEAN. W ten sposób kraj stara się przekształcić i zdywersyfikować swoją politykę zewnętrzną opartą dotąd na dwóch filarach - relacjach gospodarczych z Indonezją, która odpowiada za ponad połowę handlu zagranicznego Timoru, oraz intensywnej współpracy w sektorze bezpieczeństwa (szkolenia wojska, policji) ze stroną australijską. Pozyskanie nowego sojusznika w randze supermocarstwa ma na celu zakomunikowanie społeczności międzynarodowej, że Timor nie może być już odbierany jako państwo kruche bądź też upadające, a jego usytuowanie na przecinających się w pobliżu strategicznych drogach wodnych pozwala mu zdobyć pozycję regionalnego języczka u wagi. Dla obszaru ASEAN powinien to być wyraźny sygnał, że zawsze istnieje alternatywna forma integracji, a w przypadku Timoru jest nią porzucenie mglistych obietnic zjednoczeniowych na rzecz coraz ściślejszych związków z Chinami i zaniechanie starań o ponowne zwieńczenie sukcesem koncepcji budowania ,jednej Azji Południowo-Wschodniej”. 
Title: East Timor's Road to ASEAN - a Third-Generation-Member or Perennial Observer?

Abstract: In 2017, the Association of Southeast Asian Nations celebrated its $50^{\text {th }}$ anniversary. One of the most urgent challenges the organization has to face up is the enlargement of its structures by a group of new members, including East Timor, which has been aspiring to become part of ASEAN community since 2011. The aim of this article is to present the broad scope of bilateral relations between the organization and East Timor with special attention paid to the latter's path of accession, and an assessment of East Timor's candidature's strengths and weaknesses. Another key issue is an attempt to answer a question about the implications of East Timor's possible participation in future ASEAN.

Keywords: ASEAN, international organizations, regional cooperation, Southeast Asia, East Timor

\section{BIBLIOGRAFIA}

1. Ali M., 2011, To Admit or to Exclude Timor Leste? Implications for ASEAN integration, "RSIS Commentaries", no. 66, s. 1.

2. ASEAN Secretariat, Timor-Leste opens ASEAN National Secretariat to intensify its preparations to join ASEAN, 2 February 2009, s. 1.

3. Aquino Siapno J., 2014, Timor Leste's Preparation for Accession into ASEAN: Public Participation, Production of Knowledge, Comparative Histories, and Perspectives from Below, "Journal of Critical Perspectives on Asia", vol. 50, no. 2, s. 111.

4. Bernatowicz-Bierut G., 1982, Polityka wewnętrzna i zagraniczna Portugalii po II wojnie światowej 1945-1980, Polski Instytut Stosunków Międzynarodowych, Warszawa, s. 260.

5. Bonczol Ł., 2008, Timor Wschodni. Od reliktu kolonializmu do problemu międzynarodowego, Wydawnictwo Uniwersytetu Wrocławskiego, Wrocław, s. 38, 74.

6. Chalermpalanupap T., 2015, Timor-Leste's Quest to Join ASEAN: The Process and the Pace, "ASEAN Focus", issue 1, s. 9.

7. Dupont A., 2000, ASEAN's Response to the East Timor Crisis, "Australian Journal of International Affairs", vol. 54, no. 2, s. 164.

8. Dupont A., 2003, The Strategic Implications of an Independent East Timor, [w:] Out of the Ashes: Destruction and Reconstruction of East Timor, red. J.J. Fox, D. Babo-Soares, ANU E Press, Canberra, s. 182.

9. Gunn G.C., 2006, Complicity in Genocide: Report to the East Timor "Truth Commission" on International Actors, Tipografia Macau Hung Heng Ltda., Macau, s. 92.

10. Harris V., Goldsmith A., 2011, The struffel for independence was just the beginning, [w:] Security, Development and Nation-Buidling in Timor-Leste. A cross-sectoral assessment, red. V. Harris, A. Goldsmith, Routledge, London, s. 4.

11. Hicks D., 2015, Rhetoric and the Decolonization and Recolonization of East Timor, Routledge, London, s. 92.

12. Horta L., 2013, Timor-Leste and ASEAN: Doors Closing for Dili's Membership?, "RSIS Commentaries", s. 2.

13. Joseph A., Hamaguchi T., 2014, Timor-Leste: The History and Development of Asia's Newest Nation, Lexington Book, Plymouth, s. 143.

14. Kennes W., 2015, ASEAN and the EU: an evolving and solid development, [w:] Drivers of Integration and Regionalizm in Europe and Asia, red. L. Brennan, P. Murray, Routledge, London, s. 371 . 
15. Kin Wah C., 1997, ASEAN: The Long Road to "One Southeast Asia“", "Asian Journal of Politic Science", vol. 5, no. 1, s. 14-15.

16. Kyodo News International, ASEAN to amend its Amity Treaty if E. Timor serious to join, 29 July 2006.

17. Minister of State and of the Presidency of the Council of Ministers and Official Spokesperson for the Government of Timor-Leste, Timor-Leste ranked first in South East Asia in 2016 Democracy Index, 2 February 2017, s. 1.

18. Narine S., 2002, Explaining ASEAN. Regionalism in Southeast Asia, Lynne Rienner Publishers, Boulder, s. 173-174.

19. Ortuoste M, 2011, Timor-Leste and ASEAN: Shaping Region and State in Southeast Asia, "Asian Journal of Political Science“", vol. 19, no. 1, s. 8, 11.

20. Paul E., 2010, Obstacles to Democratization in Southeast Asia. A Study of the Nation State, Regional and Global Order, Palgrave Macmillan, New York, s. 118.

21. Ramos-Horta J., 2001, East Timor and the Region, [w:] Trends in Southeast Asia, Institute of Southeast Asian Studies, Singapore, s. 8.

22. Sahin S.B., 2010, Timor-Leste in 2009: Marking Ten Years of Independence or Dependence on International "Assistance ", "Southeast Asian Affairs", s. 359.

23. Sahin S.B., 2012, A More Confident or Overconfident Foreign Policy Actor, "Southeast Asian Affairs", s. 350, 351.

24. Sahin S.B., 2014, Timor-Leste's Foreign Policy, Securing State Identity in the Post-Independence Period, "Journal of Current Southeast Asian Affairs", vol. 33, no. 2, s. 10.

25. Scheiner C., 2015, Can the Petroleum Fund Exorcise the Resource Curse from Timor-Leste?, [w:] A New Era? Timor-Leste After the UN, red. S. Ingram, L. Kent, A. McWilliam, ANU Press, Australia, s. 83, 76.

26. Secretariat of State of the Council of Ministers, Meeting of the Council of Ministers, 16th of March of 2011, 16th March 2011, s. 1.

27. Severino R.C., 2006, Southeast Asia in Search of an ASEAN Community: Insights from the Former ASEAN Secretary-General, Intitute of Southeast Asian Studies, Singapore, s. 129, $77,79$.

28. Shoesmith D., 2011, Timor-Leste: On the Road to Peace and Prospetrity?, "Southeast Asian Affairs", s. 331.

29. Sousa-Santos J., 2015, Acting West, Looking East: Timor-Leste's Growing Engagement with the Pacific Islands Region, [w:] Regionalism, Security \& Cooperation in Oceania, red. R. Azizian, C. Cramer, Asia Pacific Center for Security Studies, Honolulu, s. 114-116.

30. Strating R., 2016, Social Democracy in East Timor, Routledge, London, s. 38.

31. The Asia Foundation, 2017, The State of Conflict and Violence in Asia, s. 184-186.

32. The Government of Timor Leste, Timor-Leste, Strategic Development Plan 2011-2030, s. 31-32.

33. The Habibie Center, 2016, Rethinking the Process for Timor-Leste's Application for ASEAN Membership, "ASEAN Briefs", vol. 3, issue 4, s. 6.

34. Thuzar M., 2017, What does it take to join ASEAN?, "Perspective", no. 36, s. 6, 3. 


\section{ŹRÓDŁA INTERNETOWE}

1. ABS CBN, ASEAN to pass on letting East Timor join grouping this year: Kyodo sources, 2017: news.abs-cbn.com/news/11google/05/17/asean-to-pass-on-lettin (dostęp: 01.07.2018).

2. Ariesta M., 2018, Indonesia Terus Bantu Timor Leste untuk Masuk ASEAN, http://internasional.metrotvnews.com/asia/3NOER87k-indonesia-terus-bantu-timor-leste-untuk-masuk-asean (dostęp: 01.07.2018).

3. East Timor Law \& Justice Bulletin, 2017, East Timor's Accession to ASEAN Treaty Still Resisted 15 Years After Restoration of Independence, http://www.easttimorlawandjusticebulletin. com/2017/11/east-timors-accession-to-asean-treaty.html (dostęp: 01.07.2018).

4. Fernandes H., Soares J., 2011, Making Timor-Leste's ASEAN Accession a People-Centric Effort, http://asiafoundation.org/2011/05/25/making-timor-lestes-asean-ascension-a-people-centric-effort/ (dostęp: 15.08.2017).

5. Financial Times, 2005, East Timor launches fund to Mouse oil revenue, http://www.ft.com/ $\mathrm{cms} / \mathrm{s} / 0 / 5$ ecf7858-2c21-11da-89bf-00000e2511 c8.html?ft_site=falcon\&desktop=true\#axzz4eWX2hPna (dostęp: 15.08.2017).

6. Focus Economics, 2015: ASEAN: Economic Progress and Integration, http://www.focus-economics.com/blog/posts/asean-economic-progress-and-integration (dostęp: 15.08.2017).

7. Go China, 2015, Ambassador of Timor-Leste on "Belt and Road Initiative ",https://www.youtube.com/watch? $\mathrm{v}=1 \mathrm{i} 3 \mathrm{kUjRGTsk}$ (dostęp: 15.08.2017).

8. Gutteres J.L., 2014, Timor Leste ready to fulfil ASEAN obligations: PM, http://www.bt.com.bn/ news-national/2014/03/18/timor-leste-ready-fulfil-asean-obligations-pm (dostęp: 15.08.2017).

9. Hamutuk L., 2015, How long will the Petroleum Fund carry Timor-Leste, http://www.laohamutuk.org/econ/model/13PFSustainability.htm (dostęp: 15.08.2017).

10. Hunt L., 2016, East Tmor Hopes for ASEAN Membership by 2017, http://thediplomat. com/2016/05/east-timor-hopes-for-asean-membership-by-2017/ (dostęp: 15.08.2017).

11. Hutt D., 2016, Is China's Influence in Timor-Leste Rising?, http://thediplomat.com/2016/11/ is-chinas-influence-in-timor-leste-rising/ (dostęp: 15.08.2017).

12. Hutt D., 2018, Political deadlock augurs ill for Timor Leste, http://www.atimes.com/article/ political-deadlock-augurs-ill-timor-leste/ (dostęp: 01.07.2018).

13. Neves G., 2018, Timor-Leste Finally Has a Government. Now What?, https://thediplomat. com/2018/05/timor-leste-finally-has-a-government-now-what/ (dostęp: 01.07.2018).

14. Pooittiwong A., Ramirez B., 2016, ASEAN Economic Integration: Opportunities and challanges that lie ahead, https://intpolicydigest.org/2016/01/06/asean-economic-integration-opportunities -and-challenges-that-lie-ahead/ (dostęp: 15.08.2017).

15. Ramos-Horta J., 2011, Why Timor-Leste should join ASEAN now, http://www.eastasiaforum. org/2011/05/16/why-timor-leste-should-join-asean-now/ (dostęp: 15.08.2017).

16. Roberston P., 2012, ASEAN's road to nowhere? Subverting standards withing the ASEAN Human Rights Declaration, https://www.hrw.org/news/2012/04/26/aseans-road-nowhere (dostęp: 15.08.2017).

17. Rosenthal S., 2015, Timor Leste belongs to ASEAN, http://www.thejakartapost.com/ news/2015/11/21/timor-leste-belongs-asean.html (dostęp: 15.08.2017).

18. Talesco C., 2016, How East Timor's Democracy Is Making It an Outcast, http://foreignpolicy. com/2016/05/10/how-east-timors-democracy-is-making-it-an-outcast-asean-southeast-asia/ (dostęp: 15.08.2017).

19. Wyeth G., 2016, How Australia and Timor-Leste Ended Up at The Hague in Arbitration, http:// thediplomat.com/2016/08/how-australia-and-timor-leste-ended-up-at-the-hague-in-arbitration/ (dostęp: 15.08.2017). 